\title{
Erasmus+ in Cologne. TH Cologne
}

\author{
Vladimir-Nicolae Nechita ${ }^{1}$ \& Cătălina-Teodora Stoian ${ }^{2}$ \\ 1vladimir.nechita@gmail.com \\ ${ }^{2}$ Faculty of Geography, University of Bucharest \\ ctstoian@yahoo.com
}

\begin{abstract}
TH Cologne" is the second article of the series "Erasmus+ in Cologne" and is intended mainly for students and researchers of the Faculty of Geography of the University of Bucharest, who want to take part in an Erasmus+ scholarship. It covers advice and relevant information regarding TH Cologne, the enrolment procedures before and after the stay and presents viable modules and study programmes for Erasmus+ geographers that can be attended at the Institute for Rescue Engineering and Civil Protection and at ITT.
\end{abstract}

Keywords: Erasmus+, TH Cologne, International Student, Rescue Engineering, ITT

\section{THE UNIVERSITY}

Founded 1971, TH Cologne is a higher education institution located in Cologne, Germany. It was established as a fusion of well-known former institutions, including the Cologne College of Higher Education for Business, the State Engineering Schools for Mechanical Construction Engineering, the German Insurance Academy, the Cologne College of Higher Education for Social Work, the old College of Higher Education for Librarianship and Documentation, the Cologne Craft Schools, the Gummersbach Campus and the Cologne State College of Higher Education for Photography. New chairs were added later such as Design, Restoration and Conservation and the Institute for Technology and Resources Management in the Tropics and Subtropics (TH Cologne, 2018a).

44 years after its foundation, in September 2015, the university became TH Köln - Technology, Arts, Sciences. TH Cologne along with 6 other universities is part of the strategic alliance UAS7, that consists of the seven leading German Universities of Applied Sciences (UAS7). Having more than 25000 students (TH Cologne, 2018b), TH Cologne is the largest university of applied sciences in Germany.

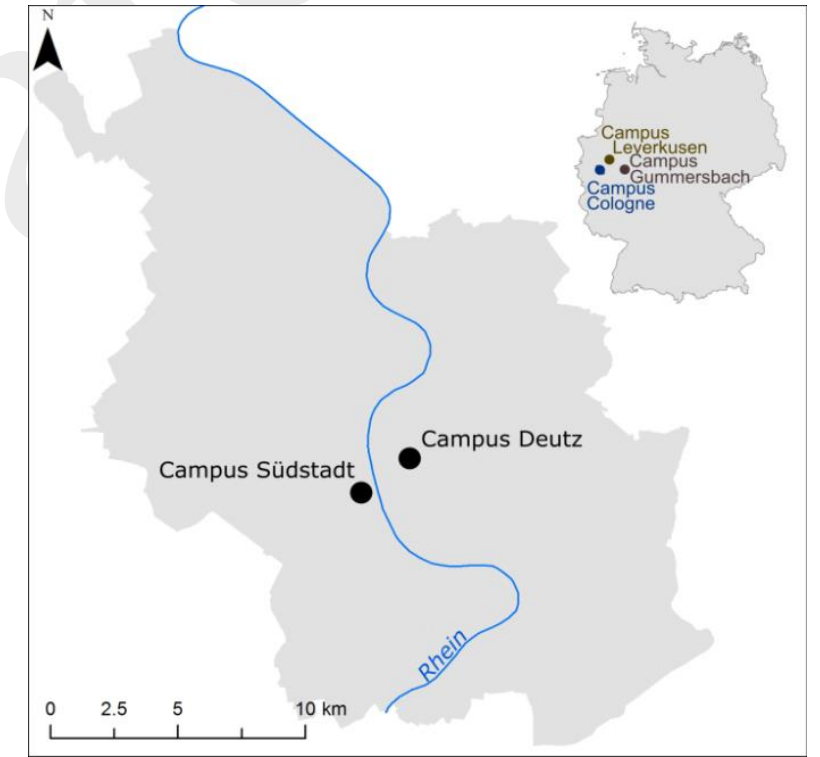

Figure 1 The location of the 4 campuses in Germany (upper right) and in Cologne (left)

TH Cologne offers 90 degree programmes (fulltime, career integrated or part-time), while the students of the university originate in more than 110 different countries. The institution comprises 420 professors and 1200 staff employees. The research at TH Cologne mainly focuses on future-related topics such as energy supply, health and food safety, climate and demographic change, since they 
collaborate with 290 international institutions of higher education. The European Commission certified TH Cologne with the quality seal "HR Excellence in Research", meeting international standards in the area of human resources development. TH Cologne's campuses (Figure 1) are located in Cologne ( 2 campuses), Gummersbach and Leverkusen (TH Cologne, 2018c).

TH Cologne comprises 11 faculties and one standalone institute as follows:

- Applied Social Sciences;

- Cultural Sciences;

- Business, Economics and Law;

- Architecture;

- Civil Engineering and Environmental Technology;

- Information, Media and Electrical Engineering;

- Automotive Systems and Production;

- Process engineering, Energy and Mechanical Systems;

- Information and Communication Sciences;

- Computer Science and Engineering Sciences

- Applied Natural Sciences;

- Institute for Technology and Resources Management in the Tropics and Subtropics.

\section{THE ENROLMENT PROCEDURES}

After arrival in Cologne, you have to reach the International Office. There are three International Offices: two in Cologne (one in Campus Südstadt, one in Campus Deutz) and one in Gummersbach. Applying for an Erasmus+ Programme at the TH Cologne on behalf of the Faculty of Geography of the University of Bucharest means that all your activities regarding academic matters will take place in the Campus Deutz. The campus can be reached by bus (line 153) or by light rail/Stadtbahn (line 1, 5 or 9) - Deutz Technische Hochschule station.

The main building of Campus Deutz is divided into four wings: North (N), South (S), West (W) and Ost/East $(\mathrm{O})$, the interior walls of each wing being painted accordingly. The purpose of different colours for each of the wings is locating easier a specific room. Each room name starts with $\mathrm{Z}$ for Zimmer (the German word for "room"), followed by one of the four regions ( $\mathrm{N}, \mathrm{S}, \mathrm{W}$ or $\mathrm{O}$ ), the floor number and the room number. For instance, $\mathrm{ZN} \mathrm{4-5}$ stays for the room located in the northern wing, in the fourth floor whose number is 5; ZO 3-11 is the room number 11 located in the eastern wing, in the third floor. The remaining buildings from the campus have different functions such as canteen and cafeteria, library or other facilities (Figure 2).

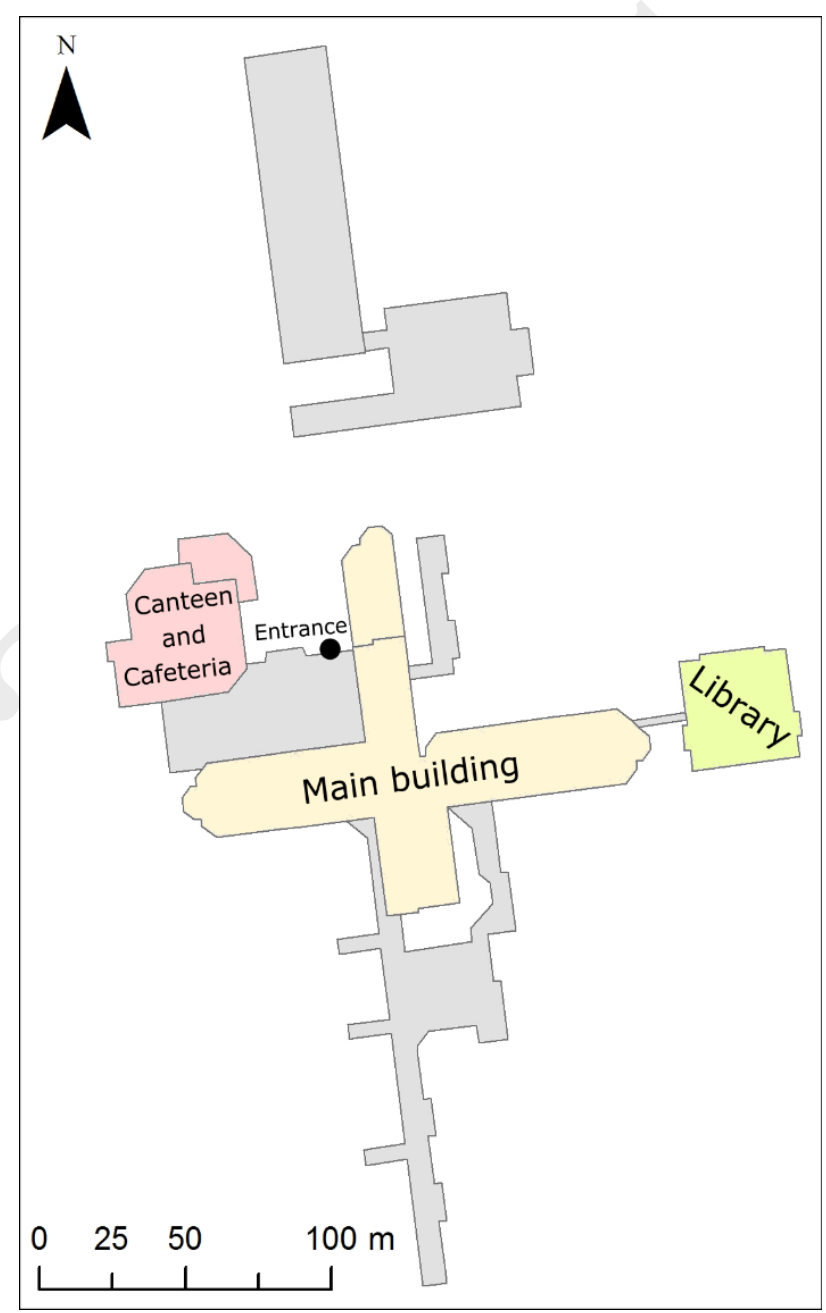

Figure 2 Campus Deutz and its main buildings

The International Office is in the room $\mathrm{ZN} \mathrm{2-4}$ on the second floor. It is important to mention that the main entrance of the university is located on the second floor, and not on the ground floor as usual. The required documents for the enrolment are: the letter of admission, a confirmation from a German statutory health insurance provider and one passport-size picture (the medical insurance you have brought - European Health Insurance Card or a private health insurance - serves as a proof to be exempt from a German statutory health insurance 
provider). There are two main statutory health insurance companies that offer you a confirmation from a German statutory health insurance: AOK or Techniker Krankenkasse (TH Cologne, 2018e).

The fee for each semester is approximately $€ 260$. This covers the semester ticket and different contributions. Payment by cash is not possible, but only by card. The fee must be paid before the start of the semester. The academic calendar with all the semester dates, including the lecture periods and the semester breaks can be found online at www.thkoeln.delen/academics/semester-dates_11444.php. The calendar is updated until 2024.

As an Erasmus+ student, you also have to provide two signed documents from your home university: confirmation of arrival/departure form and the learning agreement. The confirmation of arrivalldeparture form must be signed by the International Office with your arrival date, while the Learning Agreement must be signed by your coordinator from TH Cologne. Both must be then sent via email to the International Office from the University of Bucharest. These documents are to be provided to the International Office from Romania after you return.

Once you are enroled, you will receive on the same day a certificate of enrolment useful for different authorities in Cologne and a preliminary travel ticket within the VRS grid.

After the semester fee is paid, you will receive your student ID card by mail. Also, called MultiCa, the ID card covers as follows: the access to library, cashless payment in the student cafeterias and canteens, semester ticket within the VRS grid (Cologne and surroundings). The semester ticket for the whole state North Rhine-Westphalia can be generated online at www.asta.th-koeln.de/ semesterticket after you receive your MultiCa. This has to be printed and will be your proof once you travel in North Rhine-Westphalia outside the VRS grid. The Deutz canteen (Mensa) and cafeteria are located in the same campus. Please note that the canteen is open only for 3 hours a day around the noon, while the cafeteria has longer opening hours. Your MultiCa allows you to eat at every canteen of higher education institution from Cologne.

Besides the student ID card, you will receive your personalized campus ID by mail (note that it will be sent in two separate letters due to security reasons). The campus ID is your personal identification number and allows you to use the campus ID center, PSSO, ILIAS, your personal TH Cologne email address and the Wi-Fi service. The campus ID center can be accessed only via intranet or through VPN and is a page where you can administer your campus ID. PSSO (the Online Examination and Student Services) offers you the possibility to organize all your academic matters online and can be accessed at https://psso.thkoeln.de. In PSSO you can register or withdraw from your exams, generate certificates related to your study and even transcript of records. ILIAS (The Integrated Learning, Information and Work Cooperation System) is an online e-learning platform implemented in the whole Germany. On ILIAS lecturers have the opportunity to upload didactic material, communicate important updates, while students join for courses, get in touch with others and even upload their reports and papers (ILIAS, 2018). You can reach out ILIAS for TH Cologne at https://ilias.th-koeln.de/.

If you do not have a place of residence yet, you can ask the International Office to deliver these documents to them, on the Betzdorfer Str. 2, 50679 Cologne - that is also the official address of the Deutz campus of TH Cologne.

In case you seek technical help, the Campus IT department (http://www.campus-it.th-koeln.de/) provides IT services such as setting up your CampusID or the WiFi connection or acquiring several software licenses that are free for students.

If your stay in Germany is longer than three months, your new place of residence has to be registered at a registration office in Cologne in the first week. There are five main registration offices in Cologne. If you want to avoid the long queues, be sure to make an appointment online. More information about the location and the schedule can be found online at www.stadt-koeln.de. Registering your place of residence requires a valid passport and a Wohnungsgeberbescheinigung (signed confirmation from your landlord). If you live in a student dormitory, the signed confirmation can be provided by KSTW (Kölner Studierendenwerk/Cologne state-run nonprofit organization for student affairs). 
After the successful registration with the city of Cologne, it is recommended to open an account at a German bank. The payment of your rent and your fees require a German bank account. In order to open the account, you need a valid passport/ID, a certificate of enrolment at $\mathrm{TH}$ Cologne and the certificate of registration obtained from the registration office.

You can sign up for the KARIBU - buddy programme (a programme organized by students for new and international students at $\mathrm{TH}$ Cologne). Through this programme you can receive support from students, participate in different cultural events and free-time activities. The programme can be accessed at www.th-koeln.de/karibu.

The university library (https://www.thkoeln.de/Hochschulbibliothek) includes several books and journals in hard copy and e-resources. Besides the library located in the campus Deutz, there are three libraries in the other campuses of $\mathrm{TH}$ Cologne that you are allowed to enter. It is also possible to download books or articles in digital form on your personal computer while being connected to the intranet or to the VPN.

In addition to this, you can also sign up for the Sprachtandem programme, a language partnership programme that helps you to learn a new language by teaching your partner another language. More information about the programme can be found at www.th-koeln.de/sprachtandem.

If you still have time left and are interested in a job, the Career Service offers personal advice on career planning and informs you regarding possible long- and short-term jobs in Cologne and in the surroundings.

\section{STUDY PROGRAMMES FOR ERASMUS+ GEOGRAPHERS}

If you are a geographer, there are 2 possible opportunities to study at TH Cologne: at the Faculty 09 or at ITT.

\section{A. Faculty 09}

The faculty of Process Engineering, Energy and Mechanical Systems (Faculty 09) comprises 5 institutes:
- Institute of Chemical Process Engineering and Plant Design

- Cologne Institute of Construction Machinery and Agricultural Engineering

- Institute of Rescue Engineering and Civil Protection

- Institute of Product Development and Engineering Design

- Institute of Applied Materials

The Institute of Rescue Engineering and Civil Protection focuses on prevention and operative emergency response. The offered disciplines in civil protection and security are related to:

a. Operative Civil Protection (including Rescue Services, Catastrophe Protection and Technical Aid)

b. Preventive Civil Protection (with Environment and Civil Protection, Fire Protection and Management System)

c. Safety Technology (comprising Machine Safety, Plant and Process Safety, Worker Protection)

The disciplines in risk and crisis management are covered here through teaching and research as an interdependence between natural, technical and anthropogenic hazards and social vulnerability and critical infrastructure as follows (TH Cologne, 2018d):

- Civil protection and security

- Development cooperation

- Interdisciplinary

- Infrastructure criticality

- Natural \& man-made hazards

- Risk analysis, risk communication, risk management, risk governance

- Vulnerability and resilience

The Rescue Engineering Bachelor's programme combines engineering and knowledge for the development of effective concepts concerning hazard control and prevention. The programme comprises two branches: Rescue Engineering (RIW) and Fire Protection Engineering (BIW). The Rescue Engineering Master's programme helps the students obtaining a specialized skill set, contributing to innovative concepts not only in hazard control and prevention, but also in safety engineering (Table 1). 
Table 1 Rescue Engineering Bachelor's and Master's Programmes

\begin{tabular}{|c|c|c|c|}
\hline Programme & Certificate & $\begin{array}{c}\text { Study } \\
\text { duration }\end{array}$ & $\begin{array}{c}\text { Study } \\
\text { language }\end{array}$ \\
\hline $\begin{array}{l}\text { Rescue } \\
\text { Engineering } \\
\text { (Bachelor's } \\
\text { Programme) }\end{array}$ & $\begin{array}{l}\text { TH Köln } \\
\text { Bachelor of } \\
\text { Engineering } \\
\text { (B.Eng.) }\end{array}$ & 7 sem. & German \\
\hline $\begin{array}{l}\text { Rescue } \\
\text { Engineering } \\
\text { (Master's } \\
\text { Programme) }\end{array}$ & $\begin{array}{l}\text { TH Köln } \\
\text { Master of } \\
\text { Science } \\
\text { (M.Sc.) }\end{array}$ & 3 sem. & \\
\hline
\end{tabular}

Concerning the Rescue Engineering Bachelor's Programme there are nine relevant modules for geographers that can be attended at the Faculty 09, as shown in Table 2.

Table 2 Relevant Bachelor modules for geographers

\begin{tabular}{|c|c|}
\hline $\begin{array}{c}\text { Module } \\
\text { Semester } \\
\text { ECTS credits }\end{array}$ & Main contents \\
\hline $\begin{array}{lr}\begin{array}{l}\text { Introduction } \\
\text { rescue and }\end{array} & \text { to } \\
\text { protection } & \\
\text { engineering, } & \text { risk } \\
\text { management } & \\
& \\
I^{s t} & \\
5 E C T S & \end{array}$ & $\begin{array}{l}\text { Basic understanding of rescue } \\
\text { engineering; Similarities and } \\
\text { differences of fire safety and risk } \\
\text { management specializations; } \\
\text { Interdisciplinary overview of } \\
\text { local, national and international } \\
\text { actors; Types of emergencies, } \\
\text { crises, disasters and escalation } \\
\text { levels. }\end{array}$ \\
\hline $\begin{array}{l}\begin{array}{l}\text { Methods of } \\
\text { analysis }\end{array} \\
\text { risk } \\
\end{array}$ & $\begin{array}{l}\text { Common methods and procedures } \\
\text { of risk analysis and risk } \\
\text { assessments; Characteristic } \\
\text { features, advantages and } \\
\text { disadvantages of the methods; } \\
\text { Acquisition and evaluation of } \\
\text { empirical, statistical, temporal } \\
\text { and spatial data; Projects: } \\
\text { selection and application of } \\
\text { appropriate procedures and } \\
\text { methods for specific questions. }\end{array}$ \\
\hline $\begin{array}{ll}\text { Natural } & \text { hazards } \\
\text { and risks } & \end{array}$ & $\begin{array}{l}\text { Exogenous and endogenous } \\
\text { processes and natural conditions } \\
\text { as a basis for natural hazards; } \\
\text { Characteristics of historical and } \\
\text { recent natural hazards; Methods } \\
\text { for measuring hazards, effects, } \\
\text { risks; Complex, dynamic and } \\
\text { social-ecological feedback } \\
\text { systems. }\end{array}$ \\
\hline $\begin{array}{l}\text { Human and } \\
\text { technical hazards } \\
\text { and risks } \\
4^{\text {th }} \\
5 \text { ECTS }\end{array}$ & $\begin{array}{l}\text { System basics of technical and } \\
\text { human systems; CBRN hazards, } \\
\text { cyberattacks, infrastructure failures; } \\
\text { Measurement and observation } \\
\text { methods; Humanitarian crises and } \\
\text { conflicts. }\end{array}$ \\
\hline
\end{tabular}

\begin{tabular}{|c|c|}
\hline $\begin{array}{l}\text { Critical } \\
\text { infrastructures and } \\
\text { civil protection }\end{array}$ & $\begin{array}{l}\text { Fundamentals of infrastructures } \\
\text { and civil protection; Description } \\
\text { and analysis of critical } \\
\text { infrastructures sectors; Safety } \\
\text { goals definitions and concepts in } \\
\text { Germany and at international } \\
\text { level; State security, strategies, } \\
\text { criticality and vulnerability } \\
\text { concepts }\end{array}$ \\
\hline $\begin{array}{l}\text { Logistics and } \\
\text { management } \\
\text { systems } \\
6^{\text {th }} \\
5 \text { ECTS }\end{array}$ & $\begin{array}{l}\text { Basics of logistics; Logistics in } \\
\text { the rescue service and in } \\
\text { emergency } \\
\text { Conceptual design of logistics } \\
\text { systems; Civil protection } \\
\text { logistics. }\end{array}$ \\
\hline $\begin{array}{l}\text { Risk and crisis } \\
\text { communication }\end{array}$ & $\begin{array}{l}\text { Risk communication in risk and } \\
\text { crisis management (ISO 31010); } \\
\text { Risk perception and crisis } \\
\text { response; Stakeholder analysis; } \\
\text { Social evaluation and } \\
\text { participation. }\end{array}$ \\
\hline $\begin{array}{l}\text { Security systems in } \\
\text { international } \\
\text { comparison } \\
6^{\text {th }} \text { or } 7^{\text {th }} \\
5 \text { ECTS }\end{array}$ & $\begin{array}{l}\text { State and social structures; } \\
\text { Security systems in Europe and } \\
\text { worldwide; Cooperation in the } \\
\text { European Union and cross-border } \\
\text { security; Risks and potential } \\
\text { hazards. }\end{array}$ \\
\hline $\begin{array}{l}\text { Programmes and } \\
\text { methods in security } \\
\text { research }\end{array}$ & $\begin{array}{l}\text { Research of national security } \\
\text { research strategies and programs } \\
\text { of relevant authorities and NGOs; } \\
\text { Advanced methods in risk and } \\
\text { crisis assessment; State and } \\
\text { international security strategies; } \\
\text { Comparison of current activities } \\
\text { and priorities in security research. }\end{array}$ \\
\hline
\end{tabular}

The Rescue Engineering Master's Programme consists of three modules relevant for geographers as shown in Table 3.

Table 3 Relevant Master modules for geographers

\begin{tabular}{|l|l|}
\hline \multicolumn{1}{|c|}{\begin{tabular}{c} 
Module \\
\multicolumn{1}{|c|}{ crester, ECTS }
\end{tabular}} & \multicolumn{1}{|c|}{ Main contents } \\
\hline $\begin{array}{l}\text { Humanitarian aid } \\
\text { and international } \\
\text { development } \\
\text { cooperation } \\
2^{n d}\end{array}$ & $\begin{array}{l}\text { Humanitarian aid and } \\
\text { development cooperation actors; } \\
\text { Classic and actual solution } \\
\text { approaches; Impact orientation } \\
\text { and sustainability; Vulnerability } \\
\text { and resilience. }\end{array}$ \\
\hline $\begin{array}{l}\text { Analyses of } \\
\text { networked critical } \\
\text { infrastructure }\end{array}$ & $\begin{array}{l}\text { Interdependencies and resilience } \\
\text { of KRITIS; Criticality, } \\
\text { vulnerability and risk analysis of } \\
\text { critical infrastructures by sector; } \\
\text { Geographic information systems, }\end{array}$ \\
\hline
\end{tabular}




\begin{tabular}{|l|l|}
\hline \multirow{2}{2^{\text{nd}}}{5 ECTS } & $\begin{array}{l}\text { satellite remote sensing data, } \\
\text { statistical evaluation methods; } \\
\text { Risk governance and risk } \\
\text { management approaches. }\end{array}$ \\
\hline $\begin{array}{l}\text { Risk and crisis } \\
\text { management }\end{array}$ & $\begin{array}{l}\text { Goals, structure and challenges of } \\
\text { risk management systems; } \\
\text { Internal and external risk factors; } \\
\text { Methods of risk analysis and } \\
2^{\text {nd }}\end{array}$ \\
5 ECTS & $\begin{array}{l}\text { assessment; Strategies and } \\
\text { framework for dealing with risks. }\end{array}$ \\
\hline
\end{tabular}

Each module part of the Rescue Engineering study programme includes at least one lecture and one seminar/exercise per week. The lectures are held by a lecturer, whereas the seminars or exercises are held either by the same lecturer or by a different one. These takes usually place in a big room, where the projection of the content followed to be presented is projected. Most lecturers use interactive PowerPoint presentations and once every 3-4 weeks an expert from a state institution is invited to hold a presentation on a specific topic related to the module. During the presentation and afterwards students have the opportunity to discuss about the topic, to ask questions and even to find out more about that institution and a possible career there. The concepts and theory discussed during the lectures are put in practice through the seminars or exercises, where students can get used to the topics.

There are mainly three different ways to evaluate the performance of the students: taking an exam (Klausur), writing a report/project or both. The exams are planned for the exam session, while the deadline of the projects is usually the last lecture session of the semester. In modules with a final exam the aim of the exercises/seminars is to better understand the content discussed and to prepare for the final exam. In modules with assessments such as projects or reports the aim of the seminars is to build the teams (projects are usually carried out in teams), to choose the title of the projects and to get acquainted with the general terms of reference needed to be followed. The progress of the project status will be monitored throughout the remaining sessions during the semester.

\section{B. ITT}

The Institute for Technology and Resources Management in the Tropics and Subtropics (ITT) is part of $\mathrm{TH}$ Cologne and aims to better solve the complex issues related to environmental problems (ITT, 2018). ITT is offering programmes at postgraduate level, providing not only teaching and research, but also cooperating with major organizations worldwide.

ITT is offering three main study programmes and two similar ones with focus on other regions of the world. The duration of each study programme is 4 semesters (Table 4).

Table 4 Master's programmes at ITT

\begin{tabular}{|c|c|c|}
\hline Programme & Certificate & Structure (semesters) \\
\hline $\begin{array}{l}\text { Renewable } \\
\text { Energy } \\
\text { Management }\end{array}$ & \multirow[t]{3}{*}{$\begin{array}{l}\text { TH Köln } \\
\text { Master } \\
\text { of Science }\end{array}$} & \multirow{3}{*}{$\begin{array}{l}\mathbf{1}^{\text {st }} \mathbf{2}^{\text {nd }} \text { and } \mathbf{4}^{\text {th }}: \text { Germany } \\
\mathbf{3}^{\text {rd }}: \text { Germany/exchange } \\
\text { semester } \\
\text { Study language: English }\end{array}$} \\
\hline $\begin{array}{l}\text { Natural } \\
\text { Resources } \\
\text { Management }\end{array}$ & & \\
\hline $\begin{array}{l}\text { Integrated } \\
\text { Water } \\
\text { Resources } \\
\text { Management, } \\
\text { International }\end{array}$ & & \\
\hline $\begin{array}{l}\text { Environment } \\
\text { and } \\
\text { Resources } \\
\text { Management }\end{array}$ & $\begin{array}{l}\text { Double } \\
\text { Degree } \\
\text { Master } \\
\text { of Science }\end{array}$ & $\begin{array}{l}\mathbf{1}^{\text {st }} \mathbf{2}^{\text {nd }} \text { and } \mathbf{4}^{\text {th }}: \text { Mexico } \\
\mathbf{3}^{\text {rd }} \text { : Germany/exchange } \\
\text { semester } \\
\text { Study language: English } \\
\text { and Spanish }\end{array}$ \\
\hline $\begin{array}{l}\text { Integrated } \\
\text { Water } \\
\text { Resources } \\
\text { Management, } \\
\text { MENA }\end{array}$ & $\begin{array}{l}\text { Joint Degree } \\
\text { Master } \\
\text { of Science }\end{array}$ & $\begin{array}{l}\mathbf{1}^{\text {st }} \mathbf{2}^{\text {nd }} \text { and } \mathbf{4}^{\text {th }}: \text { Germany } \\
\mathbf{3}^{\text {rd }}: \text { Jordan } \\
\text { Study language: English }\end{array}$ \\
\hline
\end{tabular}

At ITT, there are two types of lectures: lectures and laboratories. Similar to the Rescue Engineering study programmes, lecturers use interactive PowerPoint presentations and once per month a specialist or a researcher from a different scientific or state institution will hold a presentation on a specific topic. The laboratory sessions take place in the computer laboratories, where students are instructed and learn how to use new methods, tools and software programs in accordance with the required topic. The performance of the students is being measured through reports or exams. Reports usually include an additional presentation of the topic a couple of weeks before the final deadline, when students receive feedback. Some reports require applying the knowledge gathered in the laboratory 
sessions, knowledge such as Geographic Information Systems or remote sensing.

As a full-time student, there must be attended Core modules, Methods and Tools modules and specific modules depending on each master programme. Erasmus+ students can attend any module they like (Table 5). The complete contents can be found at http://curriculum.itt.th-koeln.de/.

Table 5 Curriculum at ITT

\begin{tabular}{|c|c|}
\hline Programme & $\begin{array}{c}\text { Module } \\
\text { (Semester, ECTS credits) }\end{array}$ \\
\hline Core Modules & $\begin{array}{l}\text { - Management of Natural Resources } \\
\text { Systems (Winter, } 5 \text { ECTS) } \\
\text { - Natural Resources Economics and } \\
\text { Governance (Winter, } 5 \text { ECTS) } \\
\text { - Project and Business Management } \\
\text { (Summer and Winter, } 5 \text { ECTS) } \\
\text { - International Cooperation and } \\
\text { Development (Summer, } 5 \text { ECTS) } \\
\text { - Project I (Winter, } 5 \text { ECTS) } \\
\text { - Project II (Summer, } 5 \text { ECTS) } \\
\text { - Project III (Winter, } 5 \text { ECTS) } \\
\text { - Master Thesis Preparation (Winter, } 5 \\
\text { ECTS) } \\
\text { - Master Thesis and Colloquium } \\
\text { (Winter, 25 ECTS - Master Thesis, } 5 \\
\text { ECTS - Colloquium) }\end{array}$ \\
\hline $\begin{array}{l}\text { Methods and } \\
\text { Tools }\end{array}$ & $\begin{array}{l}\text { - Scientific Work and Research } \\
\text { Methods (Winter, } 5 \text { ECTS) } \\
\text { - Geographic Information Systems and } \\
\text { Remote Sensing (Winter, } 5 \text { ECTS) } \\
\text { - Statistics (Winter, } 5 \text { ECTS) } \\
\text { - Eco-Balancing and Decision Support } \\
\text { Systems (Summer, } 5 \text { ECTS) } \\
\text { - Empirical Social Research Methods } \\
\text { (Summer, } 5 \text { ECTS) } \\
\text { - Environmental Monitoring (Summer, } \\
\text { 5 ECTS) } \\
\text { - Economic Evaluation } \\
\text { (Winter, } 5 \text { ECTS) } \\
\text { - Environmental Assessment (Winter, } 5 \\
\text { ECTS) } \\
\text { - Entrepreneurship (Winter, } 5 \text { ECTS) }\end{array}$ \\
\hline $\begin{array}{l}\text { Renewable } \\
\text { Energy } \\
\text { Management }\end{array}$ & $\begin{array}{l}\text { - Energy Resources and Energy Systems } \\
\text { (Winter, } 5 \text { ECTS) } \\
\text { - Bioenergy and Geothermal Energy } \\
\text { (Winter, } 5 \text { ECTS) } \\
\text { - Energy Economics and Markets } \\
\text { (Summer, } 5 \text { ECTS) } \\
\text { - Energy Efficiency and Environment } \\
\text { (Summer, } 5 \text { ECTS) } \\
\text { - Photovoltaic and Solar Thermal } \\
\text { Systems (Summer, } 5 \text { ECTS) } \\
\text { - Energy Policy, Legislation and } \\
\text { Management (Winter, } 5 \text { ECTS) }\end{array}$ \\
\hline
\end{tabular}

\begin{tabular}{|c|c|}
\hline & $\begin{array}{l}\text { - Wind Energy and Hydro Power } \\
\text { (Winter, } 5 \text { ECTS) } \\
\text { - Decentralized Energy Systems } \\
\text { Planning (Winter, } 5 \text { ECTS) }\end{array}$ \\
\hline $\begin{array}{l}\text { Natural } \\
\text { Resources } \\
\text { Management }\end{array}$ & $\begin{array}{l}\text { - Land Use Systems and the } \\
\text { Environment (Winter, } 5 \text { ECTS) } \\
\text { - Soil Management (Summer, } 5 \text { ECTS) } \\
\text { - Farming Systems Economics (Summer, } \\
5 \text { ECTS) } \\
\text { - Ecosystem Management and } \\
\text { Conservation (Summer, } 5 \text { ECTS) } \\
\text { - Public Services and Housing Provision } \\
\text { (Summer, } 5 \text { ECTS) } \\
\text { - Ecological and Social Risks (Winter, } 5 \\
\text { ECTS) } \\
\text { - Food Security (Winter, } 5 \text { ECTS) } \\
\text { - Resources Efficient Buildings and } \\
\text { Quarters (Summer, } 5 \text { ECTS) } \\
\text { - Urban, Regional and Community- } \\
\text { Based Management (Winter, } 5 \text { ECTS) } \\
\text { - Water Energy Food Security Nexus } \\
\text { (Winter, } 5 \text { ECTS) }\end{array}$ \\
\hline $\begin{array}{l}\text { Integrated } \\
\text { Water } \\
\text { Resources } \\
\text { Management }\end{array}$ & $\begin{array}{l}\text { - Water Resources Management } \\
\text { (Winter, } 5 \text { ECTS) } \\
\text { - Hydrology (Summer, } 5 \text { ECTS) } \\
\text { - Hydraulic Structures (Summer, } 5 \\
\text { ECTS) } \\
\text { - Water and Agriculture (Summer, } 5 \\
\text { ECTS) } \\
\text { - Water Economics and Governance } \\
\text { (Summer, } 5 \text { ECTS) } \\
\text { - Watershed Management (Summer, } 5 \\
\text { ECTS) } \\
\text { - Sanitation and Public Health (Winter, } 5 \\
\text { ECTS) } \\
\text { - Flood Management (Winter, } 5 \text { ECTS) } \\
\text { - Water Scarcity and Drought (Winter, } 5 \\
\text { ECTS) } \\
\text { - Water Supply (Winter, } 5 \text { ECTS) } \\
\text { - Water System Analysis (Summer, } 5 \\
\text { ECTS) }\end{array}$ \\
\hline
\end{tabular}

In the end, Table 6 reveals the main differences of day-to-day activities and study structures at the Faculty09, at ITT and at the University of Bucharest.

Table 6 TH Cologne, ITT and UNIBUC-comparison

\begin{tabular}{|l|c|c|c|}
\hline Parameter & $\begin{array}{c}\text { Rescue } \\
\text { Engineering } \\
\text { (TH Cologne) }\end{array}$ & $\begin{array}{c}\text { ITT } \\
(\text { TH } \\
\text { Cologne })\end{array}$ & $\begin{array}{c}\text { Faculty of } \\
\text { Geography } \\
\text { (University } \\
\text { of } \\
\text { Bucharest })\end{array}$ \\
\hline $\begin{array}{l}\text { Lecture } \\
\text { duration }\end{array}$ & 90 minutes & $\begin{array}{c}150 \\
\text { minutes }\end{array}$ & $\begin{array}{c}100 \\
\text { minutes }\end{array}$ \\
\hline $\begin{array}{l}\text { Break } \\
\text { duration }\end{array}$ & 30 minutes & 10 minutes & 20 minutes \\
\hline
\end{tabular}




\begin{tabular}{|l|l|l|l|}
\hline Lunch break & $\begin{array}{l}13: 00- \\
14: 00\end{array}$ & $\begin{array}{l}\text { 13:05- } \\
14: 05\end{array}$ & No \\
\hline Lecture types & $\begin{array}{l}\text {-Lecture } \\
\text {-Exercise } \\
\text {-Seminar }\end{array}$ & $\begin{array}{l}\text {-Lecture } \\
\text {-Laboratory }\end{array}$ & $\begin{array}{l}\text {-Lecture } \\
\text {-Seminar }\end{array}$ \\
\hline $\begin{array}{l}\text { Bachelor } \\
\text { duration }\end{array}$ & $7 \mathrm{sem}$. & N/A & 6 sem. \\
\hline $\begin{array}{l}\text { Master } \\
\text { duration }\end{array}$ & $3 \mathrm{sem}$. & $4 \mathrm{sem}$. & $4 \mathrm{sem}$. \\
\hline
\end{tabular}

Exchange students have the chance to take part in language courses for free: www.th-koeln.del internationales/sprachlernzentrum_9102.php). The language center (Sprachlernzentrum) provides German, English, French, Italian and Spanish courses. The only requirements are to be enroled at $\mathrm{TH}$ Cologne and to submit a valid language certificate prior to your registration. If you do not hold a language certificate, you can take part in a language placement test and depending on your result, you will be assigned to the suitable language level.

\section{AFTER YOUR STAY}

Before leaving, complete following tasks:

1. Attend the OLS+ language assessment test according to https://erasmusplusols.eu.

2. Close your German bank account

3. Deregistration at the registration office

4. Hand over the keys from your apartment/dormitory room to the landlord

5. Get your certificate of arrival/departure signed

6. Complete all remaining steps in the mobility online platform for exchange students (https://www.thkoeln.de/mobility).

After your return to Bucharest, you must hand in following documents to the International Office:

1. Signed Learning Agreement for Studies

2. Changes to Learning Agreement for Studies

3. Transcript of records

4. Signed Certificate of Arrival/Departure

5. Boarding tickets or any other travel tickets related to your trip from Romania to Cologne

6. A survey concerning the performed academic activities during your stay

7. An additional sheet you must fill in, necessary to receive the last tranche of your grant

If you are convinced and want to take part in the programme, we invite you to read our last article. In the next article - Life in Cologne - you will find out more about the student life in Cologne and how to make your Erasmus+ experience memorable.

\section{REFERENCES}

ILIAS. (2018). ILIAS. Roadmap and releases. [online] Available at: https://www.ilias.de/docu/goto_docu_ pg_95608_35.html [Accessed 10 Feb. 2018].

ITT. (2018). Institute for Technology and Resources Management in the Tropics and Subtropics. [online] Available at: https://www.th-koeln.de/en/institute-fortechnology-and-resources-management-in-the-tropicsand-subtropics/institute-for-technology-and-resourcesmanagement-in-the-tropics-and-subtropics_6825.php [Accessed 02 Feb. 2018].

OpenStreetMap. (2018). Geofrabrik downloads. [online] Available at: http://download.geofabrik.de/europe/ germany.html [Accessed 03 Feb. 2018].

Offene Daten Cologne. (2016). Stadtteile. [online] Available at: https://offenedaten-koeln.de/dataset/ stadtteile [Accessed 05 Feb. 2018].

TH Cologne. (2018a). History. [online] Available at: www.th-koeln.de/en/history_6372.php. [Accessed 22 Feb. 2018].

TH Cologne. (2018b). Start des Sommersemesters 2018: TH Köln begrüßt rund 1.000 neue Studierende. Press release from 20.03.2018. [online] Available at: https://www.th-koeln.de/mam/downloads/deutsch/hoch schule/aktuell/pm/2018/pm_14_erstsemesterbegrussung _sommersemester.pdf [Accessed $21 \mathrm{Mar}$. 2018].

TH Cologne. (2018c). About. [online] Available at: https://www.th-koeln.de/en/navi-2_490.php [Accessed 19 Feb. 2018].

TH Cologne. (2018d). Fakultät für Anlagen, Energie- und Maschinensysteme. [online] Available at: https://www.th-koeln.de/anlagen-energie-und-maschi nensysteme/fakultaet-fuer-anlagen-energie--und-ma schinensysteme_2465.php [Accessed 14 Feb. 2018].

TH Cologne. (2018e). Welcome to TH Cologne. [online] Available at: https://www.th-koeln.de/mam/down loads/deutsch/internationales/publikationen/just_arrived _web_compressed_2017.pdf [Accessed 22 Feb. 2018].

UAS7. (2018). German universities of applied sciences. Alliance of excellence. [online] Available at: http://www.uas7.org/about-uas7.html [Accessed 22 Feb. 2018]. 